\title{
Toxicological evaluation of the dried hydroethanolic extract of Amaranthus spinosus L. roots in Artemia salina larvae and Sprague Dawley rats
}

\author{
Kokou Atchou ${ }^{1 *}$, Povi Lawson-Evi ${ }^{1}$, Aboudoulatif Diallo ${ }^{1}$ and Kwashie Eklu-Gadegbeku ${ }^{2}$
}

\begin{abstract}
Background: Amaranthus spinosus is a medicinal plant used in traditional medicine to treat several diseases including diabetes and its complications. The aim of this study was to prove the safety of the plant in animal health.

Methods: The dry extract was obtained following the hydroethanolic extraction of A. spinosus roots. The cytotoxicity was evaluated in vitro by incubating Artemia salina larvae with the extract for $24 \mathrm{~h}$. In vivo toxicity was assessed in Sprague Dawley rats. A single dose of $5000 \mathrm{mg} / \mathrm{kg}$ bw of extract was administered orally to female rats in acute toxicity and observed for 14 days for mortality and signs of toxicity. In subchronic toxicity, extract doses of 500 and $1000 \mathrm{mg} / \mathrm{kg}$ bw were administered orally to male and female rats for 28 consecutive days and observed for previous signs. Body weight was recorded daily and blood glucose levels every week. On day 29, blood was collected for biochemical and hematological studies. Organs were then exised for gross autopsy and histopathological examination.

Results: The in vitro study showed that the extract had a $\mathrm{LC}_{50}=1.178 \mathrm{mg} / \mathrm{mL}$ in larvae and was considered to be non-cytotoxic. Oral administration of extract at a single dose of $5000 \mathrm{mg} / \mathrm{kg}$ bw did not cause any mortality or sign of toxicity in gross necropsy. In subchronic oral toxicity, repeated doses of 500 and $1000 \mathrm{mg} / \mathrm{kg}$ bw of extract, did not also cause any mortality or significant change in body weight, relative weight of vital organs. Furthermore, hematological and biochemical parameters and histopathological examination did not show any significant change. The observed decrease in blood glucose levels did not correlate with organ damage and supports the safety of the plant. However, the reduction of LDL-cholesterol has shown that the extract can prevent cardiovascular disease.

Conclusions: This finding demonstrated that $A$. spinosus root is non-toxic with a $\mathrm{LD}_{50}>5000 \mathrm{mg} / \mathrm{kg} \mathrm{bw}$. Thus, the extract can be used for cutaneous and subchronic oral administration at doses $\leq 1000 \mathrm{mg} / \mathrm{kg}$ bw. However, further studies such as embryo/fetotoxicity, genotoxicity and neurotoxicity will be needed to prove the safety of chronic administration of the extract in patients and fetuses.
\end{abstract}

Keywords: In vitro cytotoxicity, in vivo acute toxicity, ATC method, subchronic toxicity, Amaranthus spinosus

\footnotetext{
* Correspondence: n.k.atchou@gmail.com

${ }^{1}$ Research Unit in Physiopathology, Bioactive Substances and Safety, Faculty

of Sciences, University of Lome, Box 1515, Lome, Togo

Full list of author information is available at the end of the article
}

Springer Open (c) The Author(s). 2021 Open Access This article is licensed under a Creative Commons Attribution 4.0 International License which permits use, sharing, adaptation, distribution and reproduction in any medium or format, as long as you give appropriate credit to the original author(s) and the source, provide a link to the Creative Commons licence, and indicate if changes were made. The images or other third party material in this article are included in the article's Creative Commons licence, unless indicated otherwise in a credit line to the material. If material is not included in the article's Creative Commons licence and your intended use is not permitted by statutory regulation or exceeds the permitted use, you will need to obtain permission directly from the copyright holder. To view a copy of this licence, visit http://creativecommons.org/licenses/by/4.0/. 


\section{Introduction}

Amaranthus spinosus L., commonly called spiny amaranth is a medicinal plant from Amaranthaceae family and height approximately 0.3 to $0.8 \mathrm{~m}$. This annual monoecious herb is a nitrophile, generally grows around roads, on cultivated lands and gardens [1].

Spiny amaranth has considerable pharmacological properties. In traditional medicine, the plant is used as a diuretic, analgesic, antipyretic, against leprosy, bronchitis and laxative [2]. In Togo, the whole plant is used to produce soap and the roots to treat traditionally diabetes, stomach aches, and chronic infections in children [3]. Scientific studies have reported anti-cancer [4], antimicrobial [5], antimalarial [6], antipyretic [7], analgesic [8], anti-inflammatory [9], antioxidant [10], anti-diabetic [11], hepatoprotective [12], bronchodilator [13], and anxiolytic [14] activities of $A$. spinosus. Despite the widespread use of the plant, there is not enough information on its safety in animal health.

Previous studies on the subchronic toxicity of $A$. spinosus involved whole plant extracts and did not extend to their impacts on organs in animals [15, 16]. Furthermore, the studies which aim specifically to evaluate the cytotoxicity and the histopathological impact of the dried hydroethanolic extract of the roots of $A$. spinosus have not yet been undertaken.

The contribution of this study was then to determine the histopathological impact of the dried hydroethanolic extract of $A$. spinosus and its safety in animal health for cutaneous and oral administration. The objectives were to evaluate the safety of the extract in acute cytotoxicity in Artemia salina larvae and in acute and 28-day subchronic oral toxicities in Sprague Dawley rats.

\section{Materials and methods}

\section{Chemicals and reagents}

Serum urea, creatinine, creatine phosphokinase (CPK), transaminases (ASAT, ALAT), y-glutamyltranspeptidase, triglycerides, total cholesterol, HDL-cholesterol were estimated using Cypress diagnostics reagent kits. Solvents used for hematoxylin-eosin staining in the histopathological study were also Cypress diagnostics. URIT-5160 Auto Hematology Analyzer reagents were URIT (URIT Medical Electronic CO., LTD). The dried hydroethanolic extract of $A$. spinosus roots was prepared locally.

\section{Plant materials}

Fresh roots of Amaranthus spinosus L. were collected in Dzagble (Lome) and has been identified in Laboratory of Botany and Plant Ecology of Faculty of Science, University of Lome. Voucher specimen was deposited under number 15516TOGO at the herbarium for reference. Roots were cut into small pieces and dried at the temperature of $20 \pm 2{ }^{\circ} \mathrm{C}$ in safe from light for two weeks before reducing in powder.

\section{Extract preparation}

$400 \mathrm{~g}$ of the powder of $A$. spinosus root were macerated in $4 \mathrm{~L}$ of water-ethanol mixture (50:50) for $72 \mathrm{~h}$, then filtered through Whatman filter paper $(\varnothing 150 \mathrm{~mm})$. The filtrate was evaporated to dryness at a temperature of $45{ }^{\circ} \mathrm{C}$ under vacuum using a rotary evaporator Buchi type, Germany. The extraction yield was $18.15 \%$ and the dried hydroethanolic extract obtained was stored at a temperature of $4 \pm 2{ }^{\circ} \mathrm{C}$ for tests. This choice of extract was based on the use of hydroalcoholic maceration of the roots of $A$. spinosus in traditional medicine.

\section{Artemia salina eggs}

The eggs of Artemia salina were provided by the Laboratory of Toxicology of Faculty of Health Sciences, University of Lome. They were kept at a temperature of $4 \pm 2{ }^{\circ} \mathrm{C}$.

\section{Animals}

Male and female Sprague Dawley (SD) rats weighing $150 \pm 15 \mathrm{~g}$ were used for in vivo studies. Animals were provided by the Animal Physiology Laboratory of Faculty of Sciences, University of Lome. They were housed divided by sex in cages under standard environmental conditions with free access to food and water ad libitum. Animal studies were carried out in accordance with the institutional guidelines of the Laboratory of Animal Physiology, University of Lome, registered under number 001/2012/CB-FDS-UL.

\section{In vitro cytotoxicity}

The safety of the extract was evaluated in brine shrimp larvae (Artemia salina) for $24 \mathrm{~h}$ in order to determine the cytotoxicity by contact of $A$. spinosus roots. The method is based on the survival of larvae in contact with the chemical [17]. The test was carried out by incubating $500 \mathrm{mg}$ of the eggs of Artemia salina in $500 \mathrm{~mL}$ of seawater for $48 \mathrm{~h}$ at a temperature of $28 \pm 2{ }^{\circ} \mathrm{C}$ with continuous agitation. After incubation, 16 mobile larvae from hatching eggs were incubated for $24 \mathrm{~h}$ with $2.0 \mathrm{~mL}$ of $A$. spinosus extract prepared in seawater $(25 ; 12.5 ; 6.25 ; 3.13$; $1.56 ; 0.78 ; 0.39 ; 0.20 ; 0.10$ and $0.05 \mathrm{mg} / \mathrm{mL})$. At the end, mobile larvae (surviving) were counted. The number of deaths was deduced and then analysed to determine the toxic concentration. Controls were carried out with seawater only. Larvae are considered viable for a mortality rate $<15 \%$ in controls. $n=3$. Mousseux scale [18] was used to compare the cytotoxicity of the extract: 
1. $50 \%$ lethal concentration $\left(\mathrm{LC}_{50}\right) \geq 0.1 \mathrm{mg} / \mathrm{mL}$ $=>$ non-toxic;

2. $0.1 \mathrm{mg} / \mathrm{mL}>\mathrm{LC}_{50} \geq 0.05 \mathrm{mg} / \mathrm{mL}=>$ low toxicity;

3. $0.05 \mathrm{mg} / \mathrm{mL}>\mathrm{LC}_{50} \geq 0.01 \mathrm{mg} / \mathrm{mL}=>$ moderate toxicity;

4. $0.01 \mathrm{mg} / \mathrm{mL}>\mathrm{LC}_{50}=>$ high toxicity.

\section{Acute oral administration of extract}

The acute oral toxicity of $A$. spinosus root extract was conducted in accordance with Organization for Economic Co-operation and Development (OECD) guidelines, Test No. 423, using acute toxicity class method (ATC method) [19]. This evaluation permits to determine the $50 \%$ lethal dose $\left(\mathrm{LD}_{50}\right)$ of the extract. A single dose of $5000 \mathrm{mg} / \mathrm{kg}$ bw of A. spinosus extract was administrated orally to 3 female rats $(180 \pm 5 \mathrm{~g})$ prior fasted one by one in $24 \mathrm{~h}$ interval. Thus, rats were individually observed for first $30 \mathrm{~min}$. A special attention has given during the first $4 \mathrm{~h}$ and periodically observation of the first $24 \mathrm{~h}$ before observed daily for a total of 14 days for mortality, signs of gross toxicity or behavioral changes. The body weights of rats were recorded before and weekly. On day 15 of the end of experiment, rats were sacrificed by cervical dislocation under ether anesthesia and organs were excised for necropsy. Only non-pregnant female rates were used because of their more susceptible to biochemical compounds than male rats $[20]$.

\section{Subchronic oral administration of extract}

The subchronic oral toxicity of the extract was carried out to determine the histopathological impact of A. spinosus roots on the vital organs of rats. The extract was administrated orally to rats in accordance to OECD guideline, Test No. 407 [21]. Rats weighing $150 \pm 10$ g, were divided into 3 groups of 10 ( 5 males; 5 females) and treated daily for 28 consecutive days. Group 1 and 2 received respectively $A$. spinosus extract at doses of 500 and $1000 \mathrm{mg} / \mathrm{kg} /$ day. Group 3 received only distilled water. The choice of doses of 500 and $1000 \mathrm{mg} / \mathrm{kg}$ bw was based on the therapeutic dose of $A$. spinosus which had been determined in our previous studies [3, 22]. Rats were observed daily for signs of toxicity during the experimental and body weight was recorded before gavage. Blood glucose levels were measured from the tail vein blood of rats prior fasted for $14 \mathrm{~h}$, before and weakly using Accu-Chek Active glucometer, Germany. On day 29 of the end of treatment, the blood glucose levels were measured from the tail vein blood of rats prior fasted for. Then, rats were anesthetized with ether and blood was collected from the retroorbital sinus using a capillary tube. Blood was collected in hemolysis tubes for biochemical and in EDTA tubes for hematological parameters determination. Afterwards, rats were sacrificed by cervical dislocation under ether anesthesia and organs (liver, lungs, heart, spleen, brain, kidneys, testicles, ovaries) were excised for gross necropsy and weighed. The liver, spleen and kidneys were kept in formalin $10 \%$ for histopathological studies. Biochemical and hematological analysis were performed respectively with Mindray BA-88 A Semi-Auto Chemistry Analyzer and URIT-5160 Auto Hematology Analyzer, China. Histological sections were exanimated under Olympus optical microscope equipped with a PC ocular camera, Germany.

\section{Statistical analysis}

Data of in vitro study were analysed by Microsoft Office Excel 2016. In vivo studies data were analysed by GraphPad Prism 6 software Inc., USA, and differences between groups were determined by one or two-ways ANOVA and considered statistically significant at $p<0.05$. Value were expressed as mean \pm standard error of mean (SEM).

\section{Results}

\section{In vitro cytotoxicity of extract}

All larvae used were viable ( $98.44 \%$ in controls). A. spinosus root extract had a $\mathrm{LC}_{50}=1.178 \pm 0.021 \mathrm{mg} / \mathrm{mL}$ in brine shrimp larvae of Artemia salina. The extract also had a cutoff concentration of $0.39 \mathrm{mg} / \mathrm{mL}$ from which lethality began to be observed. The concentration $6.25 \mathrm{mg} / \mathrm{mL}$ was considered to be maximum because beyond this value no survivor was observed. In other words, the cytotoxicity of the extract was dose-

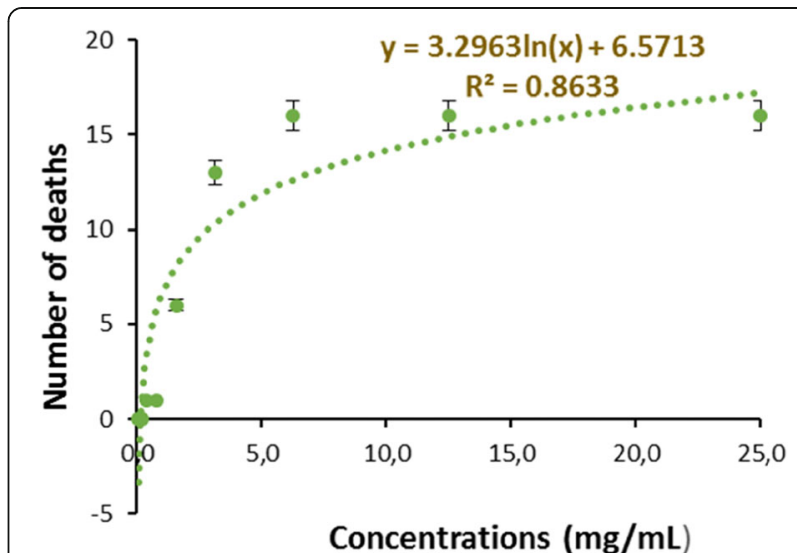

Fig. 1 Toxicity of A. spinosus root extract in Artemia salina larvae. The shrimp larvae were incubated in seawater with extract for $24 \mathrm{~h}$. After incubation, the survivors were counted and then the number of deaths was deducted. The data were analysed with Microsoft Office Excel 2016 software and expressed as the mean \pm SEM. $n=3$ 
dependent before reaching the peak at the dose of $6.25 \mathrm{mg} / \mathrm{mL}$ (Fig. 1).

\section{Acute oral administration of extract}

No mortality or clinical sign of toxicity were observed until the end of the 14 days of observation in female rats dosing by the dried hydroethanolic extract of $A$. spinosus roots at a single dose of $5000 \mathrm{mg} / \mathrm{kg}$ bw. All rats survived and no abnormalities were found in the organs at autopsy on day 15. According to the OECD limit test, the $\mathrm{LD}_{50}$ of $A$. spinosus root extract is higher than $5000 \mathrm{mg} / \mathrm{kg}$ by oral administration in rats.

\section{Subchronic oral administration of extract Effect of extract on body weight changes}

Subchronic oral administration of the extract at doses of 500 and $1000 \mathrm{mg} / \mathrm{kg}$ for 28 consecutive days did not induce significant body weight gain in male and female rats over 4 weeks compared to controls (Figs.2 and 3).

\section{Impact of the extract on organ weight}

In male and female rats, no gross abnormalities or significant changes in organs were observed at autopsy of day 29 after subchronic oral administration extract at doses of 500 and $1000 \mathrm{mg} / \mathrm{kg}$ bw. All organs had a normal relative weight compared to controls. A. spinosus root extract did not cause significant changes of the value of relative organ weights (Figs. 4 and 5 ).

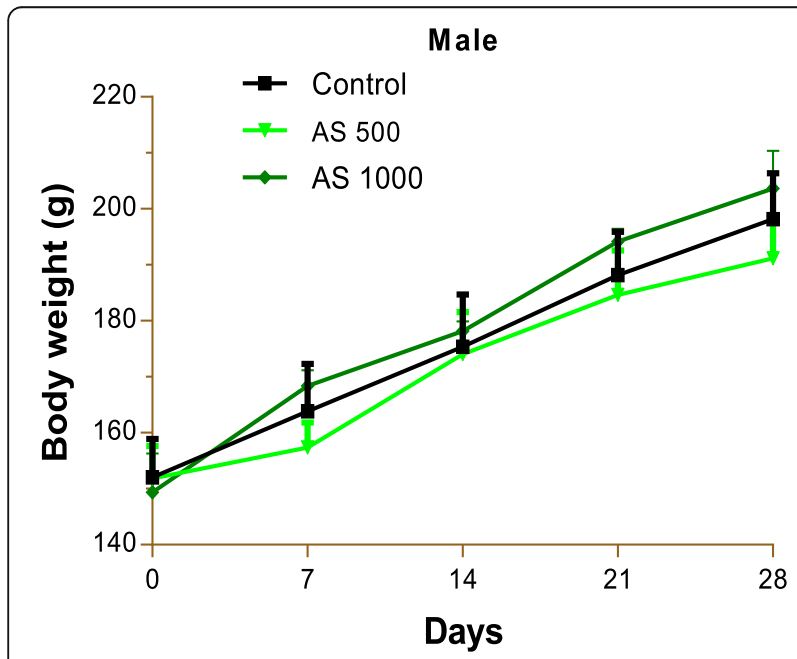

Fig. 2 Effect of $A$. spinosus root extract on body weight changes in male rats. AS $500 \& 1000=$ A. spinosus $500 \& 1000 \mathrm{mg} / \mathrm{kg}$ bw. Values were analysed with 1-ways ANOVA and then expressed as the mean \pm SEM, compared to the control. $n=5$

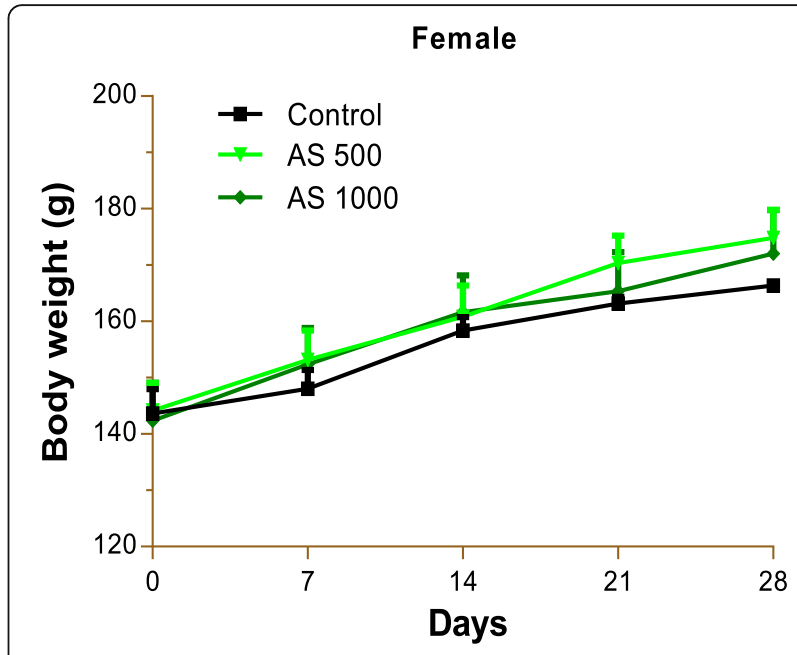

Fig. 3 Effect of A. spinosus root extract on body weight changes in female rats. AS $500 \& 1000=$ A. spinosus $500 \& 1000 \mathrm{mg} / \mathrm{kg}$ bw. Values were analysed with 1-ways ANOVA and then expressed as the mean \pm SEM, compared to the control. $n=5$

Effect of extract on basal blood glucose level

A. spinosus root extract at doses of 500 and $1000 \mathrm{mg} / \mathrm{kg}$ bw caused a decrease in basal blood glucose levels in rats during the 4 weeks of subchronic oral administration. The extract at doses of 500 and $1000 \mathrm{mg} / \mathrm{kg}$ bw caused a significant decrease $(p<0.01$ to 0.0001$)$ in basal blood glucose levels in male rats at the 1st, 2nd, 3rd and 4th week (Fig. 6). However, in female rats, subchronic oral administration of the two doses of extract caused a significant decrease $(p<0.05$ and 0.001$)$ in blood glucose levels at the 1 st and 2 nd week. The effect of $A$. spinosus root extract at doses of 500 and $1000 \mathrm{mg} / \mathrm{kg}$ bw was not

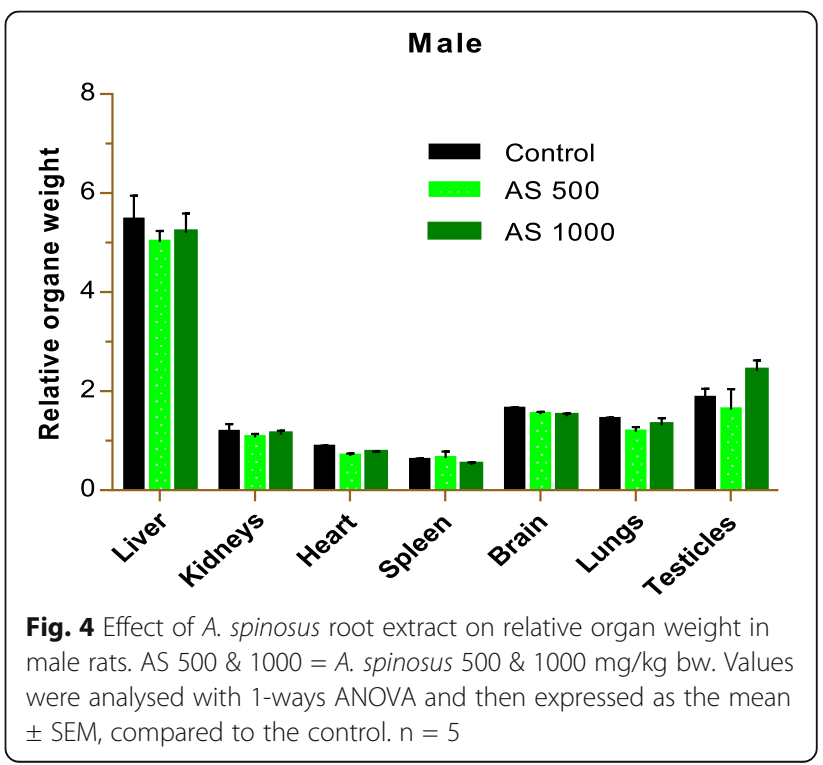




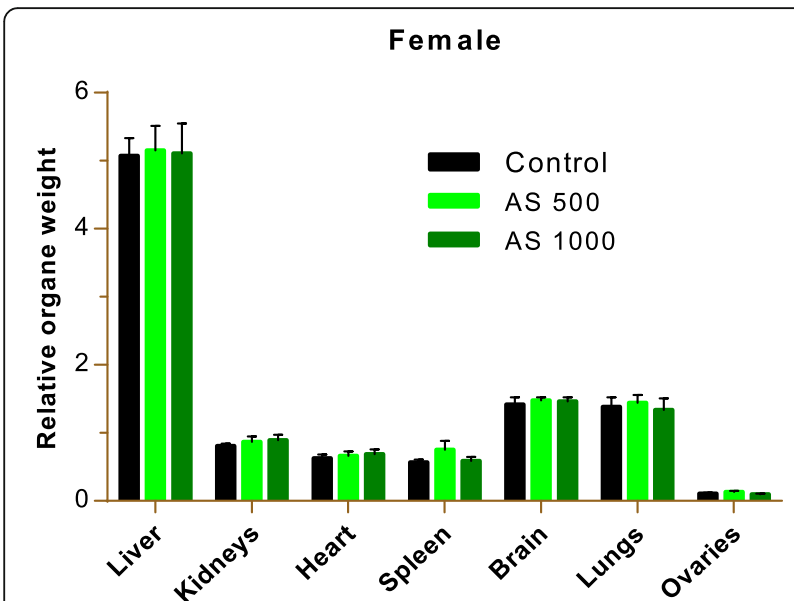

Fig. 5 Effect of $A$. spinosus root extract on relative organ weight in female rats. AS $500 \& 1000=A$. spinosus $500 \& 1000 \mathrm{mg} / \mathrm{kg}$ bw. Values were analysed with 1-ways ANOVA and then expressed as the mean \pm SEM, compared to the control. $n=5$

significant in blood glucose levels decrease in female rats at the 3rd and 4th weak (Fig. 7).

\section{Biochemical parameters}

The biochemical parameters collected on day 29, did not reveal any signs of organ damage in treated groups at doses of 500 and $1000 \mathrm{mg} / \mathrm{kg}$ compared to controls. All parameters measured were normal in male rats (Table 1). However, the extract at a dose of $1000 \mathrm{mg} / \mathrm{kg}$ bw caused a significant $(p<0.05)$ decrease in total and LDLcholesterol in female rats (Table 2).

\section{Hematological parameters}

28-day subchronic oral administration of A. spinosus root extract did not cause any significant change in

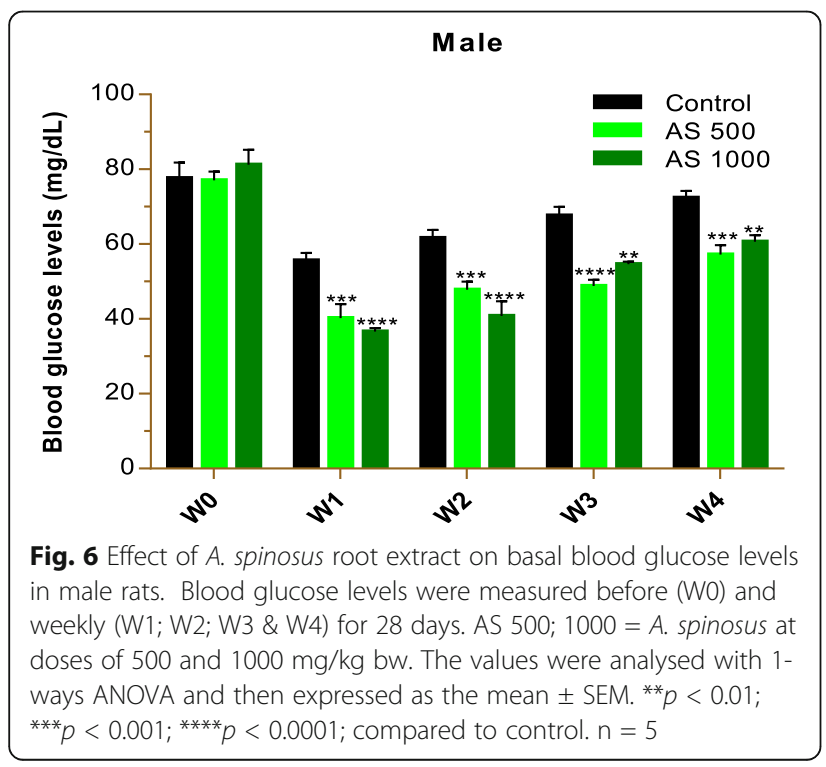

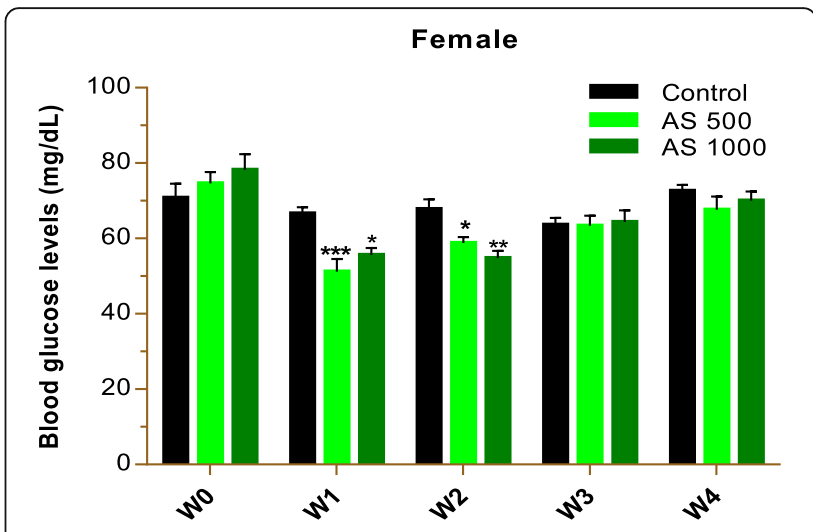

Fig. 7 Effect of A. spinosus root extract on basal blood glucose levels in female rats. Blood glucose levels were measured before (W0) and weekly (W1; W2; W3 \& W4) for 28 days. AS 500; $1000=$ A. spinosus at doses of 500 and $1000 \mathrm{mg} / \mathrm{kg} \mathrm{bw}$. The values were analysed with 1ways ANOVA and then expressed as the mean \pm SEM. ${ }^{* *} p<0.01$; ${ }^{* * *} p<0.001 ;{ }^{* * *} p<0.0001$; compared to control. $\mathrm{n}=5$

erythropoiesis in treated groups compared to controls. All hematological parameters remained normal in rats of both sexes (Tables 3 and 4).

\section{Histopathological studies}

Microscopic examination of liver, spleen, and kidney sections of male and female rats, did not reveal any sign of toxicity or necrosis or the presence of inflammatory cells in tissues. Cell nuclei had also not been modified. All organ sections of treated and control groups were normal under microscopy (Figs. 8 and 9). Thus, subchronic oral administration of extract at doses of 500 and $1000 \mathrm{mg} / \mathrm{kg}$ did not cause any damage in the liver, spleen and kidneys in both sexes of rats.

\section{Discussion}

The safety assessment of $A$. spinosus roots showed that the dried hydroethanolic extract was non-toxic in animal health, either by contact or orally in single and repeated doses.

In brine shrimp larvae of Artemia salina, the $\mathrm{LC}_{50}$ of extract was $>0.1 \mathrm{mg} / \mathrm{mL}$ on the Mousseux scale [18]. Thus, the dried hydroethanolic extract of the roots of $A$. spinosus was considered to be non-cytotoxicity. The safety of A. spinosus in brine shrimp larvae has been demonstrated by other authors. Studies previously carried out by Khanal et al. [23] on the aerial part of $A$. spinosus showed that the hexanolic $\left(\mathrm{LC}_{50}=0.237 \mathrm{mg} / \mathrm{mL}\right)$, chloroform $\left(\mathrm{LC}_{50}=0.195 \mathrm{mg} / \mathrm{mL}\right)$ and aqueous $\left(\mathrm{LC}_{50}=\right.$ $0.321 \mathrm{mg} / \mathrm{mL}$ ) extracts showed non-cytotoxicity in Artemia salina larvae. Only ethanolic extract $\left(\mathrm{LC}_{50}=\right.$ $0.032 \mathrm{mg} / \mathrm{mL}$ ) showed moderate cytotoxicity. Otherwise, Octaviani et al. [24] found that the ethanolic extract of the leaves of $A$. spinosus had a $\mathrm{LC}_{50}>0.140 \mathrm{mg} / \mathrm{mL}$ 
Table 1 Effect of $A$. spinosus on biochemical parameters in male rats

\begin{tabular}{llll}
\hline Parameters & Control & $\begin{array}{l}\text { A. spinosus } \\
\mathbf{5 0 0} \mathbf{~ m g / k g / d a y}\end{array}$ & $\begin{array}{l}\text { A. spinosus } \\
\mathbf{1 0 0 0} \mathbf{~ m g / k g / d a y}\end{array}$ \\
\hline Urea (g/L) & $0.369 \pm 0.041$ & $0.338 \pm 0.028$ & $0.285 \pm 0.044$ \\
Creatinine (mg/L) & $6.762 \pm 0.312$ & $7.600 \pm 0.303$ & $7.320 \pm 0.188$ \\
CPK (IU/L) & $593.512 \pm 53.677$ & $535.358 \pm 24.850$ & $456.034 \pm 58.569$ \\
ASAT (IU/L) & $176.060 \pm 8.968$ & $159.600 \pm 4.434$ & $163.800 \pm 6.248$ \\
ALAT (IU/L) & $60.909 \pm 4.186$ & $60.200 \pm 4.212$ & $53.600 \pm 5.344$ \\
$\gamma$-GT (IU/L) & $7.100 \pm 0.400$ & $7.600 \pm 0.678$ & $8.200 \pm 0.374$ \\
TG (g/L) & $0.600 \pm 0.079$ & $0.572 \pm 0.036$ & $0.662 \pm 0.055$ \\
TC (g/L) & $0.683 \pm 0.042$ & $0.772 \pm 0.028$ & $0.726 \pm 0.056$ \\
HDL-C (g/L) & $0.379 \pm 0.078$ & $0.542 \pm 0.032$ & $0.470 \pm 0.057$ \\
LDL-C (g/L) & $0.207 \pm 0.062$ & $0.142 \pm 0.015$ & $0.150 \pm 0.034$ \\
\hline
\end{tabular}

CPK = creatinine phosphokinase; ASAT = aspartate aminotransferase; ALAT = alanine aminotransferase; $\gamma$-GT = $\gamma$-glutamyltranspeptidase; TG = triglycerides; Total$\mathrm{C}=$ total cholesterol; HDL and LDL-C $=$ high and Low-density lipoprotein cholesterol. The values were analysed with 1 -way ANOVA and expressed as the mean \pm SEM, then compared to the control. $n=5$

(which was $>0.1 \mathrm{mg} / \mathrm{mL}$ ) and considered non-toxic on the Mousseux scale [18].

A single oral administration of the dried hydroethanolic extract of $A$. spinosus root at a dose of $5000 \mathrm{mg} / \mathrm{kg}$ bw did not result in any mortality or clinical sign of toxicity in dosed female rats during the $24 \mathrm{~h}$ and 14 days of observation. No abnormality was found in the organs at autopsy on day 15 and mean that $A$. spinosus root extract was non-toxic for oral administration with a $\mathrm{LD}_{50}>$ $5000 \mathrm{mg} / \mathrm{kg}$ bw. The extract of $A$. spinosus roots can therefore be administered at doses $<5000 \mathrm{mg} / \mathrm{kg}$ bw.

No mortality or sign of toxicity was found at the end of the experiment in male and female rats treated with the extract at doses of 500 and $1000 \mathrm{mg} / \mathrm{kg}$ bw. No significant change in body weight or organ weight were found in gross autopsy. This was confirmed by histopathological examination where sections of the liver, spleen and kidneys of rats treated at doses of 500 and
$1000 \mathrm{mg} / \mathrm{kg}$ of extract showed no sign of injury. Hematological parameters which allow detection of anemia, thrombosis and alterations in the immune system, did not reveal any significant change either. Therefore, the extract does not cause anemia, blood clotting disorder, or symptoms related to the immune system. Renal (urea, creatinine), hepatic (ALAT, ASAT, y-GT) and cardiac $(\mathrm{CPK})$ markers showed no sign of damage to these organs. The lipid (TG, TC, HDL-C and LDL-C) markers also revealed no sign of predisposition to atherosclerosis and myocardial infarction. The significant $(p<0.05)$ decrease in total cholesterol and LDLcholesterol observed in female rats treated by extract at a dose of $1000 \mathrm{mg} / \mathrm{kg}$ bw showed that the root of $A$. spinosus can be used to manage dyslipidemia and prevent cardiovascular diseases $[25,26]$. These results are consistent with other previous studies. When evaluating the effect of the leaf extract of $A$. spinosus on biochemical

Table 2 Effect of A. spinosus on biochemical parameters in female rats

\begin{tabular}{|c|c|c|c|}
\hline Parameters & Control & $\begin{array}{l}\text { A. spinosus } \\
500 \mathrm{mg} / \mathrm{kg} / \text { day }\end{array}$ & $\begin{array}{l}\text { A. spinosus } \\
1000 \mathrm{mg} / \mathrm{kg} / \text { day }\end{array}$ \\
\hline Urea (g/L) & $0.439 \pm 0.030$ & $0.404 \pm 0.030$ & $0.390 \pm 0.037$ \\
\hline Creatinine (mg/L) & $6.741 \pm 0.692$ & $7.980 \pm 0.377$ & $7.740 \pm 0.060$ \\
\hline CPK (IU/L) & $331.867 \pm 44.377$ & $282.043 \pm 40.296$ & $272.058 \pm 44.822$ \\
\hline ASAT (IU/L) & $160.011 \pm 14.493$ & $134.600 \pm 6.071$ & $135.400 \pm 7.960$ \\
\hline ALAT (IU/L) & $50.796 \pm 5.573$ & $43.200 \pm 3.734$ & $46.200 \pm 6.224$ \\
\hline$\gamma-G T(I U / L)$ & $9.600 \pm 1.400$ & $8.000 \pm 0.707$ & $8.400 \pm 0.678$ \\
\hline TG (g/L) & $0.732 \pm 0.077$ & $0.650 \pm 0.070$ & $0.748 \pm 0.042$ \\
\hline $\mathrm{TC}(\mathrm{g} / \mathrm{L})$ & $0.790 \pm 0.040$ & $0.680 \pm 0.024$ & $0.646 \pm 0.038^{*}$ \\
\hline $\mathrm{HDL}-\mathrm{C}(\mathrm{g} / \mathrm{L})$ & $0.492 \pm 0.060$ & $0.454 \pm 0.045$ & $0.470 \pm 0.013$ \\
\hline LDL-C (g/L) & $0.192 \pm 0.051$ & $0.122 \pm 0.046$ & $0.056 \pm 0.033^{*}$ \\
\hline
\end{tabular}

CPK = creatinine phosphokinase; ASAT = aspartate aminotransferase; ALAT = alanine aminotransferase; $\gamma$-GT = $\gamma$-glutamyltranspeptidase; TG = triglycerides; Total$\mathrm{C}=$ total cholesterol; $\mathrm{HDL}$ and $\mathrm{LDL}-\mathrm{C}=$ high and Low-density lipoprotein cholesterol. The values were analysed with 1 -way ANOVA and expressed as the mean \pm SEM, then compared to the control. ${ }^{*} p<0.05 . \mathrm{n}=5$ 
Table 3 Effect of A. spinosus root extract in hematological parameters in male rats

\begin{tabular}{|c|c|c|c|}
\hline Parameters & Control & $\begin{array}{l}\text { A. spinosus } \\
500 \mathrm{mg} / \mathrm{kg} / \text { day }\end{array}$ & $\begin{array}{l}\text { A. spinosus } \\
1000 \mathrm{mg} / \mathrm{kg} / \text { day }\end{array}$ \\
\hline $\mathrm{RBC}\left(10^{6} / \mu \mathrm{L}\right)$ & $6.736 \pm 0.344$ & $6.490 \pm 0.096$ & $6.464 \pm 0.141$ \\
\hline $\mathrm{HGB}(\mathrm{g} / \mathrm{dL})$ & $14.220 \pm 0.767$ & $13.700 \pm 0.266$ & $13.740 \pm 0.225$ \\
\hline HCT (\%) & $36.560 \pm 2.345$ & $35.480 \pm 0.664$ & $34.080 \pm 0.661$ \\
\hline MCV (fl.) & $54.180 \pm 0.840$ & $54.660 \pm 0.437$ & $53.600 \pm 0.896$ \\
\hline MCH (pg) & $21.480 \pm 0.240$ & $21.140 \pm 0.125$ & $21.520 \pm 0.315$ \\
\hline $\mathrm{MCHC}(\mathrm{g} / \mathrm{dL})$ & $39.500 \pm 0.404$ & $38.660 \pm 0.201$ & $40.160 \pm 0.478$ \\
\hline $\operatorname{PLT}\left(10^{3} / \mu \mathrm{L}\right)$ & $835.800 \pm 137.764$ & $836.800 \pm 22.752$ & $917.200 \pm 92.566$ \\
\hline WBC $\left(10^{3} / \mu \mathrm{L}\right)$ & $4.300 \pm 0.748$ & $5.240 \pm 0.564$ & $3.060 \pm 0.399$ \\
\hline Neutrophils (\%) & $37.000 \pm 3.302$ & $42.800 \pm 4.409$ & $31.600 \pm 3.600$ \\
\hline Eosinophils (\%) & $3.200 \pm 0.663$ & $2.800 \pm 0.735$ & $3.400 \pm 0.510$ \\
\hline Basophils (\%) & $0.000 \pm 0.000$ & $0.000 \pm 0.000$ & $0.000 \pm 0.000$ \\
\hline Lymphocytes (\%) & $55.800 \pm 1.985$ & $49.600 \pm 4.434$ & $59.200 \pm 3.583$ \\
\hline Monocytes (\%) & $4.000 \pm 1.342$ & $4.800 \pm 0.860$ & $5.800 \pm 0.860$ \\
\hline
\end{tabular}

$\mathrm{RBC}=$ red blood cells; $\mathrm{HGB}=$ hemoglobin; $\mathrm{HCT}=$ hematocrit; $\mathrm{MCV}=$ mean corpuscular volume; $\mathrm{MCH}=$ mean corpuscular hemoglobin; $\mathrm{MCHC}=$ mean corpuscular hemoglobin concentration; PLT = platelets; WBC = white blood cells. The values were analysed with 1-ways ANOVA and expressed as the mean \pm SEM, then compared to controls. $n=5$.

parameters in rats, Akinloye and Olorede [27] showed no significant change in ALT and ASAT in the treated groups compared to controls. However, Bhande and wasu [15] showed a significant decrease in total cholesterol, ASAT, ALAT, urea and triglycerides at the end of day 60 of oral administration of aqueous extract of whole plants of $A$. spinosus at doses of 500 and $1000 \mathrm{mg} / \mathrm{kg}$ bw. This could be explained by the type of plant organ used, the type of extract and especially the duration of subchronic administration. Akinloye and Olorede [27] reported no significant change in hematological parameters. However, Bhande and Wasu [16], when assessed hematological parameters over a 60day period of oral administration of aqueous extract of whole plant at a dose of $1000 \mathrm{mg} / \mathrm{kg}$ bw in male albino Wistar rats, found a significant decrease in red blood cells and hemoglobin; and increase in white blood cells. This suggests that the change in hematological

Table 4 Effect of $A$. spinosus root extract in hematological parameters in female rats

\begin{tabular}{|c|c|c|c|}
\hline Parameters & Control & $\begin{array}{l}\text { A. spinosus } \\
500 \mathrm{mg} / \mathrm{kg} / \text { day }\end{array}$ & $\begin{array}{l}\text { A. spinosus } \\
1000 \mathrm{mg} / \mathrm{kg} / \mathrm{day}\end{array}$ \\
\hline $\mathrm{RBC}\left(10^{6} / \mu \mathrm{L}\right)$ & $61.70 \pm 0.169$ & $5.894 \pm 0.109$ & $6.090 \pm 0.093$ \\
\hline HGB (g/dL) & $13.080 \pm 0.280$ & $12.440 \pm 0.406$ & $12.940 \pm 0.340$ \\
\hline $\mathrm{HCT}(\%)$ & $34.720 \pm 0.878$ & $32.780 \pm 1.058$ & $34.340 \pm 1.375$ \\
\hline MCV (fl.) & $55.420 \pm 0.828$ & $55.520 \pm 0.822$ & $56.340 \pm 1.451$ \\
\hline $\mathrm{MCH}(\mathrm{pg})$ & $20.900 \pm 0.217$ & $21.080 \pm 0.340$ & $21.240 \pm 0.256$ \\
\hline $\mathrm{MCHC}(\mathrm{g} / \mathrm{dL})$ & $37.740 \pm 0.194$ & $37.980 \pm 0.547$ & $37.780 \pm 0.653$ \\
\hline $\operatorname{PLT}\left(10^{3} / \mu \mathrm{L}\right)$ & $877.000 \pm 120.557$ & $916.200 \pm 128.117$ & $932.600 \pm 65.472$ \\
\hline WBC $\left(10^{3} / \mu \mathrm{L}\right)$ & $4.000 \pm 0.661$ & $3.700 \pm 0.633$ & $3.160 \pm 0.771$ \\
\hline Neutrophils (\%) & $31.400 \pm 6.250$ & $33.200 \pm 3.992$ & $36.200 \pm 5.826$ \\
\hline Eosinophils (\%) & $1.800 \pm 0.490$ & $2.600 \pm 0.510$ & $3.000 \pm 0.447$ \\
\hline Basophils (\%) & $0.000 \pm 0.000$ & $0.000 \pm 0.000$ & $0.000 \pm 0.000$ \\
\hline Lymphocytes (\%) & $62.400 \pm 7.089$ & $59.600 \pm 3.881$ & $55.400 \pm 5.715$ \\
\hline Monocytes (\%) & $4.400 \pm 1.691$ & $4.600 \pm 0.678$ & $5.400 \pm 0.510$ \\
\hline
\end{tabular}

$\mathrm{RBC}=$ red blood cells; $\mathrm{HGB}=$ hemoglobin; $\mathrm{HCT}=$ hematocrit; $\mathrm{MCV}=$ mean corpuscular volume; $\mathrm{MCH}=$ mean corpuscular hemoglobin; $\mathrm{MCHC}=$ mean corpuscular hemoglobin concentration; PLT = platelets; $\mathrm{WBC}=$ white blood cells. The values were analysed with 1-ways ANOVA and expressed as the mean \pm SEM, then compared to the control. $n=5$. 


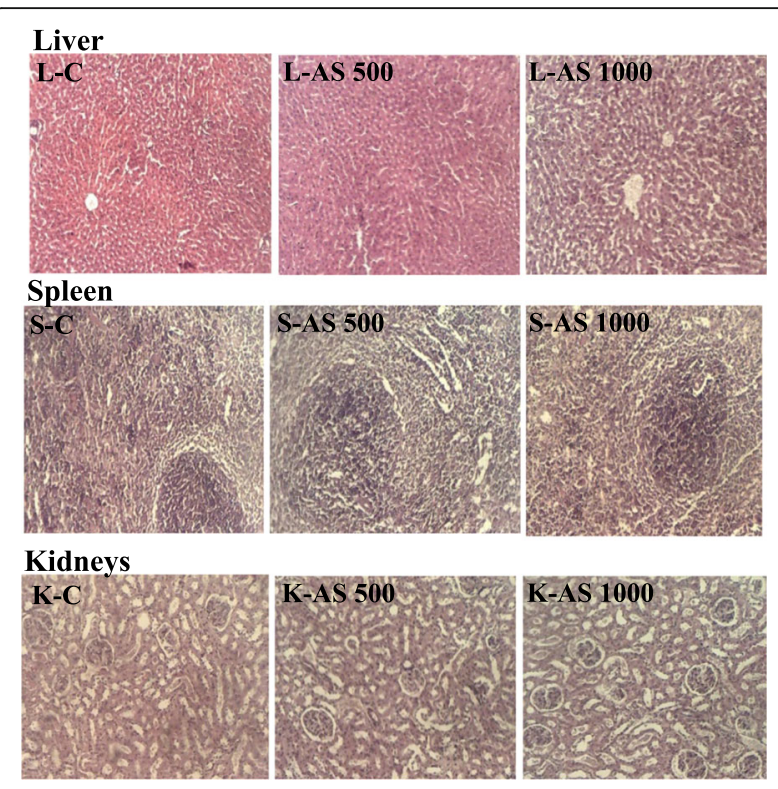

Fig. 8 Histological section of the liver, spleen and kidneys of male rats. A. spinosus root extract was administered orally for 28 consecutive days. The autopsy was carried out on day 29 of the end of treatment. L-, S- and K-C = liver, spleen and kidney of control groups having received distilled water. L-, S-, K-AS 500 and $1000=$ liver, spleen and kidney of test groups having received the extract of A. spinosus root at doses of 500 and $1000 \mathrm{mg} / \mathrm{kg} /$ day, respectively. Hematoxylin-eosin stain $\times 100$ parameters after oral administration of $A$. spinosus may depend to the method of extraction and the duration of treatment.

In this study, a significant ( $p<0.5$ to 0.001$)$ decrease in basal blood glucose level was observed in male and female rats treated with $A$. spinosus extract at doses of 500 and $1000 \mathrm{mg} / \mathrm{kg}$ bw during the 4 weeks. This decrease in basal blood glucose level in rats was in accordance with the hypoglycemic effect of the plant and could be due to phytochemicals such as flavonoids demonstrated in our previous study [3].

The in vitro and in vivo studies demonstrated that $A$. spinosus roots extract was non-toxic in animal health. The significant decrease in blood glucose level observed during the experiment was not correlated with any biochemical and hematological parameters or associated with any abnormality in the liver and kidneys in gross autopsy and in histopathological examination. Therefore, the dried hydroethanolic extract of $A$. spinosus roots can be consider safe in animal health when use for cutaneous and oral administration.

\section{Conclusions}

This study proved the safety of the dried hydroethanolic extract of Amaranthus spinosus root extract in Artemia salina larvae and rats. No cytotoxicity effect of extract

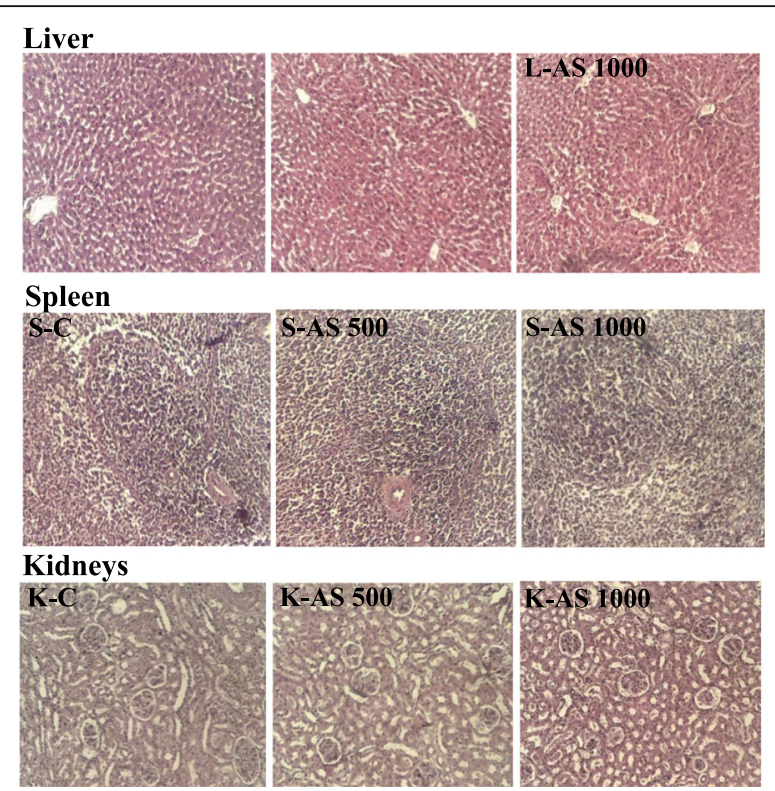

Fig. 9 Histological section of the liver, spleen and kidneys of female rats. A. spinosus root extract was administered orally for 28 consecutive days. The autopsy was carried out on day 29 of the end of treatment. L-, S- and K-C = liver, spleen and kidney of control groups having received distilled water. L-, S-, K-AS 500 and $1000=$ liver, spleen and kidney of test groups having received the extract of A. spinosus root at doses of 500 and $1000 \mathrm{mg} / \mathrm{kg} /$ day, respectively. Hematoxylin-eosin stain $\times 100$

was found in acute toxicity in brine shrimp larvae during the $24 \mathrm{~h}$. Furthermore, oral administration of A. spinosus root extract in a single and in repeated doses for 28 consecutive days, did not cause any mortality or obvious symptoms of toxicity in male and female rats. Biochemical, hematological and histopathological studies also did not show any significant change or sign of toxicity other than the observed decrease in blood glucose level. However, this decrease in blood glucose level was not correlated with any organ damage. Thus, the dried hydroethanolic extract of $A$. spinosus roots at doses $\leq$ $1000 \mathrm{mg} / \mathrm{kg}$ bw could be considered safe and used for cutaneous and oral administration without histopathological impact. However, further studies such as embryo/ fetotoxicity, genotoxicity and neurotoxicity will be needed to prove the safety of chronic administration of the extract in patients and fetuses.

\section{Abbreviations}

ALAT,: alanine aminotransferase; AS: Amaranthus spinosus; ASAT: Aspartate aminotransferase; ATC method: Acute toxicity class method; CPK: Creatinine phosphokinase; EDTA: Ethylenediaminetetraacetic acid; $\gamma$-GT: $\gamma$ glutamyltranspeptidase; HCT: Hematocrit; HDL-C: High-density lipoprotein cholesterol; HGB: Hemoglobin; LC 50 : Lethal concentration at 50\%;

$\mathrm{LD}_{50}$ : Lethal dose at 50\%; LDL-C: Low-density lipoprotein cholesterol; MCH: Mean corpuscular hemoglobin; MCHC: Mean corpuscular hemoglobin concentration; MCV: Mean corpuscular volume; OECD: Organization for 
Economic Co-operation and Development; PLT: Platelets; RBC: Red blood cells; SD: Sprague Dawley; SEM: Standard error of mean; TC: Total cholesterol; TG: Triglycerides; WBC: White blood cells

\section{Acknowledgements}

Not applicable.

\section{Authors' contributions}

KA: conceptualization, methodology, data collection, formal analysis, writing original draft of this article. PL: approved the design, supervised all research. AD: supervised in vitro study. KE: coordinated all research. All authors read and approved the final manuscript.

\section{Funding}

This work did not receive any funding from any source.

\section{Availability of data and materials} Not applicable.

\section{Declarations}

\section{Ethics approval and consent to participate}

All experiments in animals were performed in compliance with the institutional guidelines of the Laboratory of Physiology-Pharmacology, University of Lome (Togo) (001/2012/CB-FDS-UL) and approved by the National Ethics Committee.

\section{Consent for publication}

Not applicable.

\section{Competing interests}

The author declare that they have no competing interest.

\section{Author details}

${ }^{1}$ Research Unit in Physiopathology, Bioactive Substances and Safety, Faculty of Sciences, University of Lome, Box 1515, Lome, Togo. ${ }^{2}$ Department of Toxicology, Faculty of Health Sciences, University of Lome, Box 1515, Lome, Togo.

Received: 25 March 2021 Accepted: 11 July 2021

Published online: 21 July 2021

\section{References}

1. lamonico D. Taxonomic revision of the genus Amaranthus (Amaranthaceae) in Italy. Phytotaxa. 2015:199:1-84

2. Kumar BSA, Lakshman K, Jayaveera KN, Shekar DS, Kumar AA, Manoj B. Antioxidant and antipyretic properties of methanolic extract of Amaranthus spinosus leaves. Asian Pac J Trop Med. 2010;3:702-6.

3. Atchou K, Lawson-Evi P, Metowogo K, Eklu-Gadegbeku K, Aklikokou K, Gbeassor M. Hypoglycemic effect and antioxidant potential of Pterocarpus erinaceus Poir. stem bark and Amaranthus spinosus L. roots extracts. J Pharm Sci Res. 2020;12:340-50.

4. Mondal A, Guria T, Maity TK, Bishayee A. A novel tetraenoic fatty acid isolated from Amaranthus spinosus inhibits proliferation and induces apoptosis of human liver cancer cells. Int J Mol Sci. 2016. https://doi.org/1 0.3390/ijms17101604.

5. Amabye TG. Evaluation of physiochemical, phytochemical, antioxidant and antimicrobial screening parameters of Amaranthus spinosus leaves. Nat Prod Chem. 2015;4:1-5

6. Hilou A, Nacoulma OG, Guiguemde TR. In vivo antimalarial activities of extracts from Amaranthus spinosus L. and Boerhaavia erecta L. in mice. J Ethnopharmacol. 2006;103:236-40.

7. Kumar BSA, Lakshman K, Jayaveera KN. Comparative antipyretic activity of methanolic extracts of some species of Amaranthus. Asian Pac J Trop Biomed. 2011;1:47-50.

8. Zeashan H, Amresh G, Rao CV, Singh S. Antinociceptive activity of Amaranthus spinosus in experimental animals. J Ethnopharmacol. 2009;122 492-6.

9. Olajide OA, Ogunleye BR, Erinle TO. Anti-inflammatory properties of Amaranthus spinosus leaf extract. Pharm Biol. 2004;42:521-5.
10. Sarker U, Oba S. Nutraceuticals, antioxidant pigments, and phytochemicals in the leaves of Amaranthus spinosus and Amaranthus viridis weedy species. Sci Rep. 2019. https://doi.org/10.1038/s41598-019-50977-5.

11. Ashok Kumar BS, Lakshman $\mathrm{K}$, Nandeesh $\mathrm{R}$, et al. In vitro alpha-amylase inhibition and in vivo antioxidant potential of Amaranthus spinosus in alloxan-induced oxidative stress in diabetic rats. Saudi J Biol Sci. 2011;18:1-5.

12. Zeashan $\mathrm{H}$, Amresh $\mathrm{G}$, Singh S, Rao CV. Hepatoprotective activity of Amaranthus spinosus in experimental animals. Food Chem Toxicol. 2008;46: 3417-21.

13. Chaudhary MA, Imran I, Bashir S, Mehmood MH, Rehman NU, Gilani AH. Evaluation of gut modulatory and bronchodilator activities of Amaranthus spinosus Linn. BMC Complement Altern Med. 2012. https://doi.org/10.11 86/1472-6882-12-166.

14. Abid M, Gosh AK, Khan NA. In vivo psychopharmacological investigation of Delphinium denudatum and Amaranthus spinosus extracts on Wistar rats. Basic Clin Neurosci. 2017;8:503-12.

15. Bhande SS, Wasu YH. Effect of aqueous extract of Amaranthus spinosus on biochemical parameters of Wistar albino rats. Life sci leafl. 2016:75:1-9.

16. Bhande SS, Wasu YH. Effect of aqueous extract of Amaranthus spinosus on hematological parameters of Wistar albino rats. J Exp Biol Agric Sci. 2016;4 116-20.

17. Houmènou V, Adjatin A, Assogba F, Gbénou J, Akoègninou A. Etude phytochimique et de cytotoxicité de quelques plantes utilisées dans le traitement de la stérilité féminine au Sud-Benin. Eur Sci J. 2018:14:156-71.

18. Mousseux M. Test de toxicité sur larves d'Artemia salina: entretien d'un élevage de balanes. Tech. Rep., DEUST Aquaculture, Noumea, France: Centre Universitaire de Nouvelle-Calédonie; 1995.

19. OECD (Organization of Economic Co-operation and Development). Test No. 423: Acute oral toxicity - Acute toxic class method, OECD guidelines for the testing of chemicals, Sec. 4. Paris: OECD publishing; 2002.

20. Lipnick RL, Cotruvo JA, Hill RN, Bruce RD, Stitzel KA, Walker AP, Chu I, Goddard M, Segal L, Springer JA, Myers RC. Comparison of the up-anddown, conventional LD50, and fixed-dose acute toxicity procedures. Food Chem Toxicol. 1995;33:223-31.

21. OECD (Organization of Economic Co-operation and Development). Test No. 407: Repeated dose 28-day oral toxicity study in rodents, OECD guidelines for the testing of chemicals, Sec. 4. Paris: OECD publishing; 2008.

22. Atchou K, Lawson-Evi P, Eklu-Gadegbeku K. In vitro study of protective effect of Pterocarpus erinaceus Poir. stem bark and Amaranthus spinosus L. root extracts on cataractogenesis and glomerulopathy. Bull Natl Res Cent. 2021; 45:1-9.

23. Khanal DP, Raut B, Dangol KS. Phytochemical screening, pharmacognostic evaluation and biological activity of Amaranthus spinosus L. JMMIHS. 2015;1 29-34.

24. Octaviani CD, Lusiana M, Zuhrotun A, Diantini A, Subarnas A, Abdulah R. Anticancer properties of daily-consumed vegetables Amaranthus spinosus, Ipomoea aquatica, Apium graveolens, and Manihot utilisima to LNCaP prostate cancer cell lines. J Nat Pharmaceut. 2013:4:67-70.

25. Sangameswaran B, Ramdas P. Antihyperglycemic and antihyperlipidaemic activities of Amaranthus spinosus Linn extract on alloxan induced diabetic rats. Malays J Pharm Sci. 2010;8:13-22.

26. Girija K, Lakshman K, Udaya C, Sachi GS, Divya T. Anti-diabetic and anticholesterolemic activity of methanol extracts of three species of Amaranthus. Asian Pac J Trop Biomed. 2011;1:133-38.

27. Akinloye OA, Olorede BR. Effect of Amaranthus spinosus leaf extract on haematology and serum chemistry of rats. Niger J Nat Prod Med. 2000;4:7981.

\section{Publisher's Note}

Springer Nature remains neutral with regard to jurisdictional claims in published maps and institutional affiliations. 